\title{
First detection of Leishmania infantum (Kinetoplastida: Trypanosomatidae) in Culicoides spp. (Diptera: Ceratopogonidae)
}

Darine Slama ${ }^{1}$, Najoua Haouas ${ }^{1}$, Latifa Remadi ${ }^{1}$, Habib Mezhoud ${ }^{1}$, Hamouda Babba ${ }^{1,3}$ and Emna Chaker ${ }^{2 *}$

\begin{abstract}
Background: Culicoides (Diptera: Ceratopogonidae) species are known to be the vectors of Bluetongue virus and African Horses Sickness virus (AHSV) in different areas of the world. Nevertheless, other researchers have hypothesized that these arthropods could be involved in the transmission of other pathogens such as Schmallenberg virus, Plasmodium and Leishmania parasites. Identification of the Culicoides' potential vector competence is crucial in understanding the worldwide Culicoides/Leishmania life cycle.

Findings: Blood fed and parous females of biting midges Culicoides spp. were collected between 2009 and 2010 in Central Tunisia. DNA was extracted from individual blood fed Culicoides and used as a template in a genus-specific PCR. Leishmania DNA was detected in 14 Culicoides imicola specimens and one Culicoides circumscriptus. In a second step, parasite identification was performed based on a single copy Topo-isomerase II gene specific amplification and sequencing. Leishmania infantum was identified in two infected Culicoides spp.

Conclusion: This is the first report of Leishmania DNA detection from naturally infected wild caught Culicoides spp. Our finding supports the assumption that Culicoides spp. are a potential vector for L. infantum.
\end{abstract}

Keywords: Vector competence, Biting midge, Leishmania transmission

\section{Findings}

Biting midges of the genus Culicoides are known to be vectors of a wide range of pathogens, most notably arboviruses [1]. In early research on Leishmania transmission, Culicoides have been suspected to be vectors of Leishmania donovani in India [2]. However, since this date and until the beginning of the 20th century, no data were published concerning the potential involvement of biting midges in Leishmania transmission. Between 2004 and 2010, some researchers reported the natural infection of Culicoides biting midges by Herpetomonas and Sergeia kinetoplastid protozoa [3-5].

In 2011 Dougall et al. [6] reported the natural infection of Forcypomyia day-feeding midges with Leishmania using both molecular approach and microscopic detection of promastigotes in their gut. Recently, Seblova [7] have experimentally proved the susceptibility of reared Culicoides

\footnotetext{
* Correspondence: emna.chaker@rns.tn

${ }^{2}$ Laboratory of Parasitology and Mycology, Tunis, La rabta, Tunisia

Full list of author information is available at the end of the article
}

nubeculosus to infection with Leishmania infantum. All these previous studies have highlighted the potential role of midges in the Leishmania transmission.

Moreover, other studies have demonstrated the infection of domestic dogs (reservoirs of L. infantum) with BlueTongue Virus (BTV) in Morocco [8]. This implies that Culicoides can feed on canine hosts and thereby transmission of $L$. infantum by this arthropod genus is possible.

In our study, we emphasize the likelihood of Leishmania transmission via Culicoides.

Insects were collected between 2009 and 2010 in Central Tunisia, using two light traps types: home-made CDC (Center of Disease Control, Atlanta, USA) miniature and OVI (Onderstepoort Veterinary Institute) traps in rural areas. Traps were set before sunset and collected the next morning. All insects were collected in a beaker filled with $70 \%$ ethanol. Sampled insects were carried to the laboratory and Culicoides were separated from other insect genera. Females Culicoides specimen were divided into engorged (i.e. insects with a full or partial blood meal), parous and unfed midges. For each female specimen,

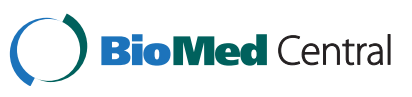


wings and genitals were mounted for morphological identification using Chaker's key [9].

Total DNA from each individual, blood fed or parous, biting midge abdomen and head, was extracted and PCR was performed to detect Leishmania DNA.

In the first step, DNA from all specimens (blood fed and parous) was tested using genus-specific PCR primers targeting a part of small subunit rRNA gene for the detection of Leishmania spp. infection according to the protocol of Spanakos et al. [10]. In the second step, DNA from positive specimens was re-analyzed by a second set of primers targeting a Topo-isomerase II single copy gene. PCR products from this last PCR were sequenced for identification of Leishmania to the species level according to the protocol of Haouas et al. [11].

In total, 259 biting midges of Culicoides (blood fed, $\mathrm{n}=189$; parous, $\mathrm{n}=70$ ) were tested for Leishmania spp. infection. Morphological identification showed that these tested midges belonged to the following species: Culicoides imicola $(\mathrm{n}=196)$, C. jumineri $(\mathrm{n}=35)$, C. cataneii $(\mathrm{n}=3), C$. paolae $(\mathrm{n}=10), C$. newsteadi $(\mathrm{n}=10), C$. circumscriptus $(\mathrm{n}=3)$ and C. sp. (unidentified Culicoides) $(\mathrm{n}=2)$. Among these collected samples, 15 Culicoides specimens were positive for Leishmania spp. DNA using genus-specific PCR primers. To confirm this result all positive PCR products were sequenced and sequences were blasted using Blastn algorithm against the "non-redundant" GenBank sequence database. These positive specimens belonged to $C$. imicola species $(\mathrm{n}=14)$ and $C$. circumscriptus species $(\mathrm{n}=1)$. All of them were engorged females and no parous female was positive for Leishmania spp. In the 15 positive specimens only two were positive for Leishmania Topo-isomerase II gene primer set. They correspond to C. imicola $(\mathrm{n}=1)$ and $C$. circumscriptus $(\mathrm{n}=1)$. The sequencing of these Topo-isomerase II positive PCR products confirmed the presence of $L$. infantum DNA in the abdomens of both Culicoides species. It is the first case in the world of Leishmania DNA detection from wild caught biting midges Culicoides. This preliminary finding highlights the potential role of this insect in Leishmania transmission. Our result corroborates the findings of Seblova et al. who have succeeded to experimentally infect reared C. nubeculosus with L. infantum [7].

It is noteworthy that even phlebotomine sand flies captured in the same area as biting midges were positive for Leishmania DNA in their mid gut. Among them three Phlebotomus perniciosus specimen were infected with L. infantum [12]. This result indicates that L. infantum could be transmitted by more than one arthropod genus. This assumption is supported by the studies of Coutinho et al. who have reported the presence of $L$. infantum DNA and promastigote forms in Rhipicephalus sanguineus (tick) and Ctenocephalides felis felis (fleas) respectively $[13,14]$.
Despite infected biting midges are blood fed the hypothesis of contaminated blood meals could be excluded. Indeed, infected engorged females were also analyzed to identify their blood meal origin according to the protocol of Haouas et al. [11] and Homo sapiens, Capra hircus and Gallus gallus hosts were identified (unpublished data). These hosts are not known to be reservoirs of Leishmania in Tunisia. The presence of L. infantum DNA in Culicoides specimens fed on animals that are not regarded as reservoirs of the parasite may indicate that these female Culicoides would have taken their first blood meal from Leishmania reservoirs (the $\operatorname{dog}$ in the case of L. infantum in Tunisia). Then, these females would have taken a second blood meal (just before being captured) from uninfected hosts (human, goats or chicken).

Our preliminary findings raise important questions to solve in future epidemiological studies on the Leishmania life cycle. Therefore, to confirm the vector role of Culicoides in Leishmania transmission, studies should be accompanied by direct microscopic observations to confirm Leishmania development and survival.

\section{Conclusion}

Our study reports for the first time the detection of Leishmania DNA in the abdomens of wild caught Culicoides spp. Nevertheless, further studies such as the isolation of the parasite and its iso-enzymatic identification are mandatory to confirm this preliminary result.

\section{Competing interests}

The authors declare that they have no competing interests.

\section{Authors' contributions}

Conceived and designed the experiments: DS, HB, EC and NH. Performed the experiments: DS and LR. Drafted the manuscript: DS, NH, HB, and EC. Participated in field missions: DS, HB. All authors read and approved the final manuscript.

\section{Acknowledgements}

We are indebted to Dr. Larry Hribar (Director of Research, Florida Keys Mosquito Control District) for comment on this work and we thank Nawel Essabeh for proofreading this manuscript.

\section{Author details}

${ }^{1}$ Clinical Biology Department, Laboratory of Medical and Molecular Parasitology-Mycology code LR12ES08, Faculty of Pharmacy, Monastir, Tunisia. ${ }^{2}$ Laboratory of Parasitology and Mycology, Tunis, La rabta, Tunisia. ${ }^{3}$ Laboratory of Maternity and Neonatology Center of Monastir, Monastir, Tunisia.

Received: 11 August 2013 Accepted: 13 December 2013 Published: 25 January 2014

\section{References}

1. Mellor PS, Boorman J, Baylis M: Culicoides Biting Midges: their role as arbovirus vectors. Ann Rev Entomol 2000, 45:307-340.

2. Christophers SRHE, Barraud PJ: Culicoides and kala-azar in Assam. Indian J Med Res 1925, 13:175-176.

3. Podlipaev S, Pka JV, Jirku M, Svobodova M, Lukes J: Herpetomonas ztiplika n. sp. (Kinoplastida: Trypanosomatidae): a parasite of the blood sucking Biting midge Culicoides kibunensis Tokunaga, 1937 (Diptera: Ceratopogonidae). J Parasitol 2004, 90(suppl 2):342-347. 
4. Svobodova M, Zidkova L, Cepicka I, Obornik M, Lukes J, Votypka J: Sergeia podlipaevi gen. nov., sp. nov. (Trypanosomatidae, Kinetoplastida), a parasite of biting midges (Ceratopogonidae, Diptera). Int I Syst Evol Microbiol 2007, 57:423-432.

5. Zidkova L, Cepicka I, Votypka J, Svobodova M: Herpetomonas trimorpha sp. nov. (Trypanosomatidae, Kinetoplastida), a parasite of the biting midge Culicoides truncorum (Ceratopogonidae, Diptera). Int J Syst Evol Microbiol 2010, 60:2236-2246.

6. Dougall AM, Alexander B, Holt DC, Harris T, Sultan AH, Bates PA, Rose K, Walton SF: Evidence incriminating midges (Diptera: Ceratopogonidae) as potential vectors of Leishmania in Australia. Int J Parasitol 2011, 41:571-579.

7. Seblova V, Sadlova J, Carpenter S, Volf P: Development of Leishmania Parasites in Culicoides nubeculosus (Diptera: Ceratopogonidae) and Implications for Screening Vector Competence. J Med Entomol 2012, 49(suppl 5):967-970.

8. Oura CA, El Harrak M: Midge-transmitted bluetongue in domestic dogs. Epidemiol Infect 2011, 139:1396-1400.

9. Chaker E: Contribution à l'étude des Culicoides (Diptera: Ceratopogonidae) de Tunisie: Systématique, chorologie et écologie. Strasbourg: DEA; 1981.

10. Spanakos G, Patsoula E, Kremastinou T, Saroglou G, Vakalis N: Development of a PCR-based method for diagnosis of Leishmania in blood samples. Mol Cell Probes 2002, 16:415-420.

11. Haouas N, Garrab S, Gorcii M, Khorchani H, Chargui N, Ravel C, Mezhoud H, Babba H: Development of a polymerase chain reaction-restriction fragment length polymorphism assay for Leishmania major/Leishmania killicki/Leishmania infantum discrimination from clinical samples, application in a Tunisian focus. Diag Micro Inf Dis 2010, 68:152-158.

12. Chargui N, Haouas N, Slama D, Gorcii M, Jaouadi K, Essabbah-Aguir N, Mezhoud H, Babba H: Transmission of visceral leishmaniasis in a previously non-endemic region of Tunisia: detection of Leishmania DNA in Phlebotomus perniciosus. J Vect Ecol 2012, 38:1-5.

13. Coutinho ZTM, Bueno LL, Sterzik A, Ricardo Toshio Fujiwara RT, Botelho JR, Maria MD, Genaro O, Linardi PM: Participation of Rhipicephalus sanguineus (Acari: Ixodidae) in the epidemiology of canine visceral leishmaniasis. Vet Parasitol 2005, 128:149-155.

14. Coutinho ZTM, Linardi PM: Can fleas from dogs infected with canine visceral leishmaniasis transfer the infection to other mammals? Vet Parasitol 2007, 127:320-325.

doi:10.1186/1756-3305-7-51

Cite this article as: Slama et al:: First detection of Leishmania infantum (Kinetoplastida: Trypanosomatidae) in Culicoides spp. (Diptera: Ceratopogonidae). Parasites \& Vectors 2014 7:51.

\section{Submit your next manuscript to BioMed Central and take full advantage of:}

- Convenient online submission

- Thorough peer review

- No space constraints or color figure charges

- Immediate publication on acceptance

- Inclusion in PubMed, CAS, Scopus and Google Scholar

- Research which is freely available for redistribution

Submit your manuscript at www.biomedcentral.com/submit
(O) Biomed Central 